\title{
Imaging Features of Eyelid Pilomatraixoma
}

\author{
Bhoj Raj Sharma, Xiaolin Xu, Nannan Xu, Manisha Bajracharya, Madhu Gupta, \\ Qinghai Yuan* \\ Department of Radiology, Norman Bethune College of Medicine, Second Hospital of Jilin University, \\ Changchun, China \\ Email: "yuanqinghai123@sina.com
}

Received 2 March 2014; revised 2 April 2014; accepted 10 April 2014

Copyright (C 2014 by authors and Scientific Research Publishing Inc.

This work is licensed under the Creative Commons Attribution International License (CC BY).

http://creativecommons.org/licenses/by/4.0/

(c) () O Open Access

\begin{abstract}
Pilomatrixoma is an uncommon benign tumor of matrix cells of hair follicles that rarely involves eyelids. Here we present a case of 4-year-old girl who was brought to hospital with swelling in the left upper eyelid which increased gradually in 1 year. Computed tomography revealed calcified soft tissue mass. The mass was excised successfully and sent for histopathological examination that showed encapsulated tumor composed of eosinophilic ghost cells and basophilic cells suggestive of pilomatrixoma.
\end{abstract}

\section{Keywords}

Pilomatrixoma, Calcifying Epithelioma, Computed Tomography, Ultrasound

\section{Introduction}

Pilomatrixoma was first described by Albert Hippolyte Malherbe and J. Chenantais as calcifying epithelioma in 1880 A.D. [1]. It is common in ages between 9 months to 50 years. The imaging modalities like Computed Tomography Scan (CT) and Magnetic Resonance Imaging (MRI) are very important tools for the diagnosis of this kind of rare disease. However, pilomatrixoma is diagnosed by histopathology which shows characteristic basophilic and shadow cells. Here we discuss a rare case of pilomatrixoma of upper eyelids in 4 years old girl.

\section{Case Report}

A 4 years old girl presented to the hospital with a small painless lesion in the left eye. On examination; a small, round, non-tender, palpable nodule was present on left upper eyelid. Ultrasonography (US) showed a heterogeneous, hypo echoic, irregular and well defined lesion measuring $0.7 \mathrm{~cm} \times 0.5 \mathrm{~cm}$ in size (Figure $1(C)$ ). Further CT scan was done which revealed $0.7 \mathrm{~cm} \times 0.5 \mathrm{~cm}$ soft tissue mass with inner calcium deposition (shown in

${ }^{*}$ Corresponding author. 

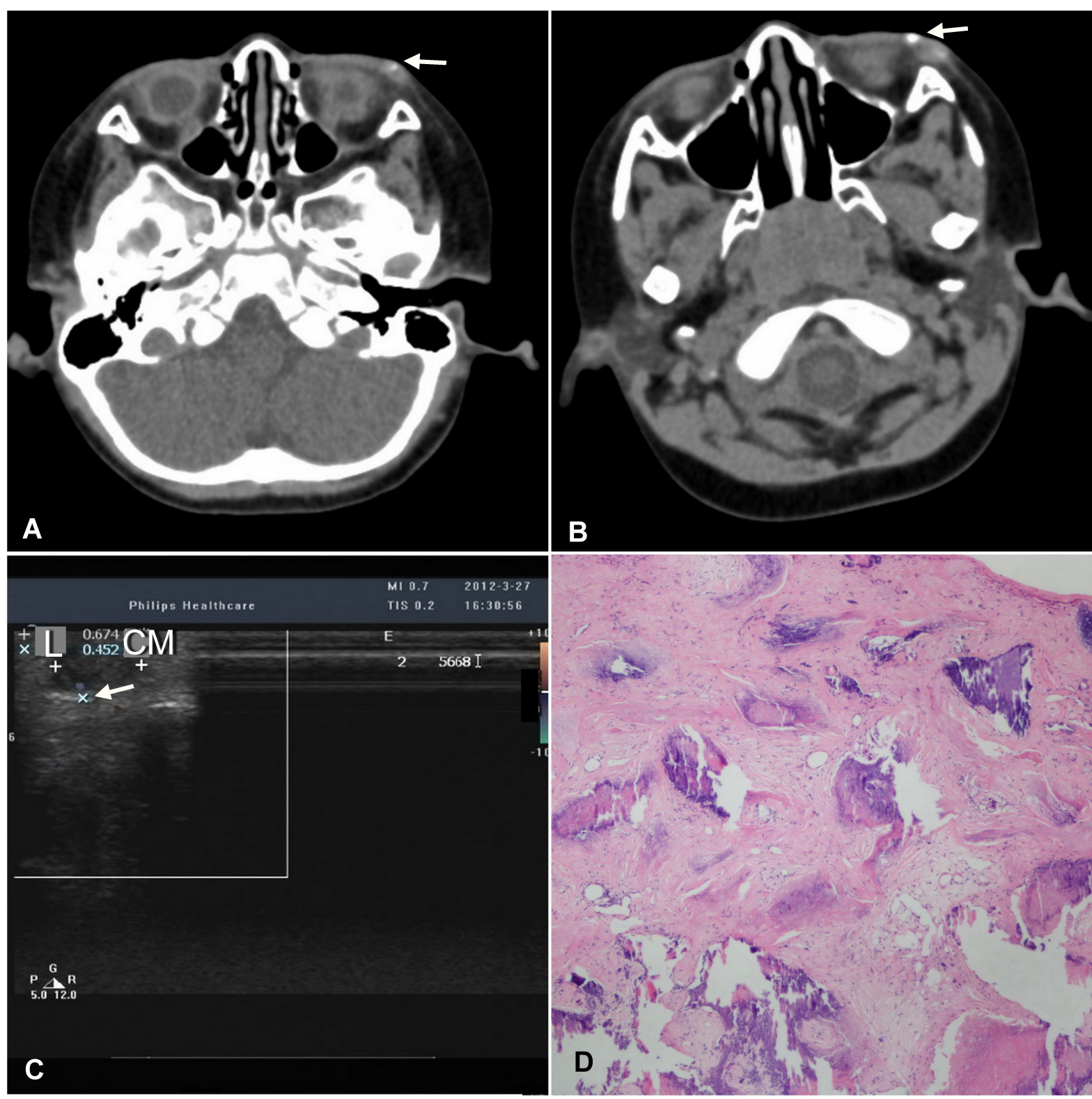

Figure 1. (A) Soft tissue mass with inner calcium deposition of size $0.7 \mathrm{~cm} \times 0.5 \mathrm{~cm}$. (B) Soft tissue mass with inner calcium deposition of size $1.2 \mathrm{~cm} \times 0.7 \mathrm{~cm}$. (C) Heterogeneous, hypo echoic, irregular and well defined lesion measuring 0.7 $\mathrm{cm} \times 0.5 \mathrm{~cm}$ in size. (D) Irregular Island of ghost cells in centre and basophilic cells in periphery.

Figure 1(A), pointed by arrow). The parents of our patient was advised for surgical excision but refused. After one year, child again presented in our hospital with same swelling in left upper eyelid that was hard, tender and markedly increases in size this time. CT scan was performed which showed $1.2 \mathrm{~cm} \times 0.7 \mathrm{~cm}$ size soft tissue mass with inner calcium deposition (shown in Figure 1(B), pointed by arrow), increased as compared to previous image. The patient was admitted and surgical excision was done successfully. The biopsy specimen showed Irregular Island of ghost cells in centre and basophilic cells in periphery that consistent with pilomatrixoma as shown in Figure 1(D).

\section{Discussion}

Pilomatrixoma was introduced by Forbis and Helwing in 1961, though it was first described as calcifying epithelioma [2]. It occurs commonly in children $<20$ years but, it has been found to occur in wide range of ages 1 - 
85 years. The male/female ratio is approximately 1:2 (ratio decreases among the elderly and increases in younger group) [1] [3]. An activation of $\beta$ catenin gene CTNNBI mutation may be the cause for development of familial pilomatrixoma [4]. Most common sites are head, neck, upper extremities and trunk and rarely eyebrows and eyelids [5]. Our case was a 4 years old female child and it occurred in the eyelid where it is rarely seen.

Clinically it manifests as asymptomatic, benign solitary, soft and friable to hard nodules measuring $0.5 \mathrm{~cm}$ to $5.0 \mathrm{~cm}$. It is subcutaneous slow growing tumor which may or may not be attached to the skin and mobile over underlying structures. It may also present as multiple and nodular pattern in $2 \%-10 \%$.

Grossly tumors are well circumscribed nodules or cystic masses with or without skin tethering (punctum). On cut section it is grey, white or brown with yellow materials [2]. Microscopically pilomatrixoma is located superficially in dermis cutaneous tissue. It consists of epithelial cells lined by basophilic cells deposited in sheets bands or irregular islands filled with keratinized ghost (shadow) cells in centre, as shown in our case [2] [3]. Mostly calcium gets deposited in these shadow cells.

Plain film typically reveals a nonspecific, well circumscribed lesion with regular border and gross homogeneous calcification. Some articles reported as well-defined hypoechoic rim with echogenic centre or hyper, iso or hypoechoic subcutaneous masses with posterior shadowing [6]-[8]. The findings were consistent with the US findings in our case. The different echogenicity of pilomatrixomas results from differences on echogencity of comparing tissue. It may be adjacent muscle, subcutaneous tissue, connective tissue capsule. Posterior acoustic shadowing is due to intramural calcification or ossification. According to Lim et al., internal anechoic area is due to cystic degeneration [8]. Color Doppler US shows central and peripheral flow signals. CT shows well-defined, non-infiltrating mild to moderately enhanced subcutaneous masses with varying degree of calcification as shown by our case [7]-[9]. In MRI, lesion shows a mass with homogenous, intermediate signal on T1W1, heterogeneous intermediate to high signal intensity on T2W1.

In our case, preoperative US and CT gave us the useful information that the tumor was just below the skin. However, the inner heterogeneous echo in US and calcium deposits as well as mild enhancement in CT suggests pilomatrixoma.

Complete surgical excision is the known best treatment. Spontaneous regression of pilomatrixoma has not been described. In some cases, overlying skin should be excised and removed. The recurrence is rare around $2 \%$ $-4 \%$.

\section{References}

[1] Malherbe, A. and Chenantais, J. (1880) Note Sur L'epitheliome calcifie des glades sebacees. Programme Med, 8, 826-828.

[2] Forbis Jr., R. and Helwing, E.B. (1961) Pilmatrixoma (Calcifying Epithelioma). Archives of Dermatology, 83, 606-618.

[3] Yencha, M.W. (2001) Head and Neck Pilomatrixoma in the Pediatric Age Group: A Retrospective Study and Litrature Review. International Journal of Pediatric Otorhinolaryngology, 57, 123-128. http://dx.doi.org/10.1016/S0165-5876(00)00449-3

[4] Chan, E.F., Gat, U., Mc Niff, J.M. and Fuchus, E. (1999) A Common Human Skin Tumor Is Caused by Activating Mutation of $\beta$-Catenin. Nature Genetics, 21, 410-413. http://dx.doi.org/10.1038/7747

[5] Hsu, H.C. and Lin, H.F. (2004) Eyelid Tumors in Children: A Clinicopathological Study of a 10-Year Review in Southern Taiwan. Ophthalmologica, 218, 274-277. http://dx.doi.org/10.1159/000078620

[6] Hwang, J.Y., Lee, S.W. and Lee, G.M. (2005) The Common Ultrasonographic Features of Pilomatrixoma. Journal of Ultrasound in Medicine, 24, 1397-1402.

[7] Lee, K.H., Kim, H.J. and Suh, C.H. (2000) Pilomatrixoma in the Head and Neck: CT Findings in Three Patients. Journal of Computer Assisted Tomography, 24, 332-335. http://dx.doi.org/10.1097/00004728-200003000-00028

[8] Lim, H.W., Im, S.A., Lim, G.Y., Park, H.J., Lee, H., Sung, M.S., Kang, B.J. and Kim, J.Y. (2007) Pilomatrixomas in Children: Imaging Characteristics with Pathologic Correlation. Pediatric Radiology, 37, 549-555. http://dx.doi.org/10.1007/s00247-007-0461-x

[9] Duflo, S., Nicollas, R., Roman, S., Magalon, G. and Triglia, J.M. (1998) Pilomatrixoma of the Head and Neck in Children: A Study of 38 Cases and a Review of the Litrature. Archives of Otolaryngology-Head and Neck Surgery, 124, 1239-1242. http://dx.doi.org/10.1001/archotol.124.11.1239 